\title{
The Sustainability Practices and Its Effect on Financial Leakages of Star Classified Hotels in Ethiopia
}

\author{
Mr. ENDALEW TEGEGNE BEHAILE (PhD) \\ School of Management Studies, Punjabi University, Patiala \\ APAR SINGH $(\mathrm{PhD})$ \\ School of Management Studies, Punjabi University, Patiala
}

\begin{abstract}
The purpose of this study was to test the effects of sustainability practice on financial leakage. Furthermore, it has aimed at to investigate the effect of the reduction of financial leakage on competitive advantage of star classified hotels from managers' perspective. A quantitative and cross-sectional approach was applied. Data were collected from all 242 star classified hotel \& resorts using a survey questionnaire. To this end, after addressing data screening issues 201 of observations were left for this research analyses. CFA and SEM were applied to validate and to test the structural model respectively. The major findings were the higher sustainability practices of these star classified hotels could not more likely to reduced financial leakage of the studied star classified hotel in Ethiopia. Albeit, this research has brought a valuable insight on dimensions of financial leakage in star classified hotels/resorts has offered and the degree of sustainability practices and its implication for the reduction of financial leakage of star classified hotels in the country. Therefore, hotels in Ethiopia should give due attention for a better sustainability practices implementation so that financial leakage reduced greatly and finally competitiveness of these hotels enhanced.
\end{abstract}

Keywords: sustainability, financial leakage, competitive advantage

DOI: $10.7176 /$ RJFA/12-3-05

Publication date: February $28^{\text {th }} 2021$

\section{INTRODUCTION}

The concept of sustainable development was first defined in the 1980s Brundtland report. Since then sustainability has been discussed for years and it was adapted by tourism industry starting from the conception sustainable tourism development (Butler, 1991; Hughes, 1995). It has also defined as "tourism that takes full account of its future and current economic, environmental and social impacts, addressing the needs of the enterprises, visitors, local people and the environment (WTO \& UNEDP, 2005). Based on this, organizational level sustainability is a systematic management effort by corporations to balance environmental and societal with economic goals in order to minimize harm to and increase benefits for natural environments and societies (Dyllick \& Hockerts, 2002).

The largest sources of economic effect of tourism are the direct tourist expenditure on service providers such as hotels, tour operators, attractions and on other ancillary services. However, larger portion of these expenditures would be leaked outside of the local economies, which ultimately reduce its effect on the local economy (Supradist, 2004). This portion of profit received from tourism activities, but out flow from the local economy due to consumptions \& taxes is called financial leakage (Rahman, I., Reynolds, D., \& Svaren, S., 2012).

As a result, according to Esty \& Winston, (2006) many organizations and countries have adopted sustainability practices as a remedy to tackle the challenges and design as a strategy to reduce their financial leakage as well as enhance their competitive advantage. Until now, few researchers have attempted to test empirically the components of sustainability economic, socio-cultural and environmental sustainability practices as aggregate that would reduce financial leakage and enhance competitiveness. Thus, there is a dearth of research on the effect of sustainability to financial leakage in different destinations settings and tourism businesses (AragónCorrea \& Rubio-Lopez, 2007; Leonidou, et al. 2013). Consequently, this research has aimed at to integrate firms' resource view as theoretical stands to link sustainability practices with financial leakage and competitive advantage in Ethiopian hotel context. Finally, this research finding has indicated star classified hotels in Ethiopia have begun to alleviate societal and environmental issues through 'Triple Bottom Line'.

\section{LITERATURE REVIEW}

\subsection{Sustainability practices}

The idea of Brundtland report in 1987 has impacted world's debate issues and sustainability has received a wide attention. Hence, the integration of ecological and social aspects into products, processes, and organizational structures is become a prominent debatable agenda in different businesses. The concept of sustainability has its origin in the environmentalism since 1960s (Butler, 1999). The term 'sustainable development' is defined as "development that meets the needs of the present without compromising the ability of future generations to meet their own needs" (WCED, 1987). Sustainable tourism has been discussed for years and it was adapted by tourism 
industry starting from the conception of sustainable tourism development (Butler, 1991; Hughes, 1995). Hence, it is defined as "tourism that takes full account of its future and current economic, environmental and social impacts, addressing the needs of the enterprises, visitors, local people and the environment (WTO \& UNEDP, 2005). On basis of this definition, organizational level sustainability is a systematic management effort by corporations to balance environmental and societal with economic goals in order to minimize harm to and increase benefits for natural environments and societies (Dyllick \& Hockerts, 2002).

\subsection{Sustainability Practices at Organizational Level}

Travel and tourism companies have recognized sustainable practices and green initiatives as a strategy intended to support brand awareness. Sustainability practices oblige tourism service providers to improve their ability to use environmental resources optimally, maintain the authenticity of the local community, and ensuring sound economic stands (Spencereley, A.2001). The definition of WCED (1987) on sustainability has become the foundation to describe the organizational-level concept of corporate sustainability. The organizational level sustainability is a systematic management effort by corporations to balance environmental and social with economic goals in order to minimize harm to and increase benefits for natural environments and societies. These three aspects of sustainability i.e. environmental, economic and social aspects should not be seen as separated issues; rather, they have to be integrated (Dyllick \& Hockerts, 2002).

Organizations concerning for the economic aspect of sustainability such as, growth, profit, shareholder return, and organizations concerning, social aspect tends to focus on community issues, human right, etc; meanwhile, organizations regarding environmental view includes various kinds of pollutions, emission reduction, wastes, etc, will not stand alone. Nevertheless, the intersections of each aspects of sustainability are needed be discussed in a holistic way due to the interrelationship of each dimension (WTO \& UNEDP, 2005). Therefore, tourist companies' become aware of their obligations on positive or negative impacts related to the business, so that many of them adhere to sustainable tourism (Diamantis, 2010). They are required to balance the economic, social and environmental aspects of the business. The majority of hotel businesses in particular have already adopted sustainable practices, which enabled them to reduce the unnecessary inputs (Smerecnik \& Andersen, 2011).

\subsection{Sustainability Model in Tourism Businesses}

Currently, businesses are incorporating new concepts that extend financial agendas to take environmental and social business dimensions into their business' day to day activities. This is mainly to practice the three pillars of the UNWTO's definition of sustainable tourism. The first one is economic sustainability, concerns about the businesses for generation of prosperity and the cost-effectiveness of all economic activities. The second one is the socio-cultural sustainability pillar; which is about human rights and equal opportunities for all of humanity, unbiased allocation of tourism benefits, respect of different cultures and the avoidance of any form of misuse or cultural destruction. The last dimension is environmental sustainability, refers to conserving and managing resources in such a way that the pollution of air, land and water is minimized and diversity of biological and natural heritage are preserved (UNWTO, 2012). Thus, hotels as a major component of tourism industry have attempted to incorporate these pillars in their strategic goals and fulfill their customers' requirements. Mihalic (2009) has extended the three-pillar sustainability model i.e. the socio-cultural, economic and environmental pillars of sustainability into a $3+3$ sustainability model measure sustainability practices in hotel industry. The fourth additional requirements would be customer satisfaction (a precondition for sustaining).

The Concept of Triple Bottom Line (TBL): Elkington, (1986) has described TBL as "it is a planning and reporting system and decision making framework that focuses on measuring and controlling companies' economic, environmental and social performance". Therefore, sustainability involves the integration of social and environmental aspects with economic issues; it is an extension of the "triple bottom line" measurement of sustainability performance. Triple Bottom Line (TBL) tourism industry have little awareness or its relevance to the achievement of sustainable development was not well understood so far (Dwyer, 2005). The triple bottom line (TBL) has linked 'bottom---line' performance (profitability), with social and environmental performance to have total sustainability (Blackburn, 2007).

Environmental Sustainability: It is all about managing and conserving resources, in particular those that are nonrenewable or precious in terms of life support. Thus, tourism sectors require action to minimize their pollution of air, land and water, and to conserve biological diversity and natural heritage.

Social Sustainability: tourism or any other activities should respect human rights and equal opportunities for all in society, irrespective of their races, religion, gender, age and their physical abilities. A benefit gained out of these activities needed to be equitably distributed with a focus on alleviating poverty. Enterprises interactions with local communities should be maintained and strengthening their life support systems is crucial. Recognizing and respecting cultural diversity and avoiding any form of exploitation and safety health, global climate change, environmental regulations, etc. as well need to be considered in their operations.

Economic Sustainability: it is a level of economic gains from the activities should be sufficient either to cover 
the cost of expended to cater the tourists and to mitigate the effects of the tourist's presence or/and the inconvenience caused to the local community visited- without violating any of the other conditions' or both. Moreover, job creation, labour training, local economic impact, etc. can be considered as economic sustainability aspects which can be impacted by tourism organizations.

The study of Sousa Filho, et al(2010), have recognized the main advantages Carrefour's CSR obtained were the image of the corporation and its reputation enhancement, employee motivation and motivation etc. though it was not enough to offer other advantages, like, employee retention. However, sustainability is taking a large portion in societies mind, business strategies, company's regulation and the scope of various NGO. The hotel sustainability in cities can be achieved through investments in new technologies, but have along payback period (Baker \& Sinkular, 2005). Studies found that a link between social initiatives improved financial performance (Arag' on Correa, 1998; Sharma \& Vredenburg, 1998). To measure if a proactive attitude towards sustainability implies better financial performance is important for scholars, but also for the decisions taken in the industry. Hence, sustainability of hotels in terms of social and environmental performance affects economic performance. First, the hotel-specific sustainability performance may positively affect hotels' financial leakage. Second, these financial leakage reduction enhance hotels' competitiveness performance by cost reduction or/and service differentiation performance (Yenidogan, A. et al, 2016).

\subsection{Financial Leakages}

In economic impact assessment, the meaning of leakage is used to analyze factors that cause money out of a given 'economy' through saving, taxation, payment for import (Lejarraga \& Walkenhorst, 2010). Leakage can be also be defined as the amounts subtracted from tourist expenditure on taxes, repatriated profits, wages paid outside the region, and on imported goods and services. Tourism leakage has been defined as a portion of tourist expenditure that leaks out through imports and returns to foreign factors of production. The higher the value of these values will be the lower the value of a multiplier; hence the lower the economic impact that tourist expenditure (money injection) could generate to that given economy. Lejarraga \& Walkenhorst, have also identified the reasons are mainly related to because the local organizations do not have adequate resources to meet the international brand affiliation and to ensure quality. Leakage in tourism can be different. It shows the strength or weakness of local industry and the entrepreneurial environment or other strategies like sustainability.

According to Galdon, et al., (2013) leakage can be external, pre-leakage, internal leakage, invisible leakage. Leakage can be occurred in different forms in tourism businesses (e.g. hotels, resorts, travel agents, and tour operators) in the following ways.

- The hotel manage their organization through foreign based organization

- The reservation and communications systems is installed and managed by foreign organization

- Import semi and processed raw materials...

- Marketing and promotion expenses abroad

- Payments for foreign tour operators and agencies

- Education abroad and training costs of tourism employees

- Foreign loans including commissions paid to foreign banks and credit cards and for agencies used by tourists.

\subsection{Sustainability and Financial Leakage Multiplier Effects}

Income earned from tourism activities, in turn spend locally, creates jobs in local service sectors and employees spending their increased income locally this is delineated as tourism multiplier effect (Krikelas, 1992). Financial leakages could be a problem in many industries and sectors; it is particularly relevant in tourism as one of the few profitable economic sectors for developing countries (Mowforth \& Munt, 2003). Tourism businesses have less money to re-spend or re-inject into the economic system in the next rounds due to high level of saving, taxation, and import. Therefore, the total economic impact from tourist expenditure that is originally injected into the economy will be restricted. Tourist expenditure at a destination is either sent back to its country of origin. For example, when a tourist purchases imported goods or services or it leaves in the first places of tourists such as travel agency commissions, foreign airline tickets and tour operator profits (Lacher \& Nepal, 2010).

The firms' recourse view has been used to explain the link between sustainability and financial leakage. The theory asserts that the total change in economic, socio-cultural and environmental performance of a firm as internal resource of a firm could reduce firms' financial leakage (Barnely, 1991). The theory suggest that if a firm could configure its internal resources in a way that increase its economic, socio-cultural and environmental performances the money that will expended outside the local will be decreased. Hence, RBV has link with the level of sustainable tourism development practices within tourism business. Particularly, hotels could reduce financial leakage. It might be through companies and employees of companies to generate additional income and employment. 
Furthermore, it is well recognized that tourism has higher multiplier effects in terms of creating additional jobs and income to the local or regional economy than other sectors due to the multisided of the industry. Though, the level of multiple effects in each subsequent re-spending reduced the total effect is much higher than the original spending or injection (Krikelas, 1992).

The theory assumes firms have to get additional income out of goods and services produced within the economy through using locally available raw materials. Tourism in general and hotel sectors in particular is considered to create significant economic effects in terms of job and income (Lacher \& Nepal, 2010). But, currently it is contributing less particularly in developing countries as compared to developed countries, due to the problem behind financial leakages. For instance, the finding of a study by Karagiannis Nikolaos \& Witter Michael (2004) in the Caribbean tourist destinations shows the multiplier ratio is below 1 , which is 0.39 per dollar of tourist spending.

\subsection{Financial leakage and Competitive Advantage in Tourism Businesses}

Assaf, et al., (2012) analyzed the impact of TBL on firm performance in Slovenian hotels using the Data Envelopment Analysis (DEA) method and they found that environmental, social and financial issues led to improved hotel performance. Sustainability practices (TBL) could mitigate financial leakage problems in hotels and the reduction of financial leakage could enhance competitive advantage of the hotels (Supradist, 2004). To address this issue, the study conducted in hotels and guest houses showed how reducing leakage enhanced competitive (Galdón Salvador, 2013). He further found that reducing leakage has the potential to improve the level of satisfaction among employees and customers, thereby improving a firm's competitive advantage. Financial leakages occur in many industries and sectors, including in tourism industry. It is considerably occurring in tourism business as one of the few profitable economic sectors for developing countries. Studies shows production value of tourism actually left the host country and only a small portion stays at host destination. For instance, when a tourist purchases imported goods or services through travel agency commissions, foreign airline tickets, and tour operator profits (Mowforth \& Munt, 2003).

According to Aznar et al., (2016) actions that specifically conducted to reduce costs to a level lower than competitors are aimed to have scale economies advantage, which generally result in large market share in a growing market. Hence, there are elements in hotel operations where costs can be reduced through sustainable practice. For example, efforts to encourage sustainability and reduce waste will reduce costs which may lead to overall cost leader in the industry and may increase profits by encouraging less waste. In contrast, some environmental friendly practices such as bio-fuels energy is seen as expensive and work against achieving cost based competitive advantage. Similarly, saving costs on employing people by using volunteers, etc may be perceived as not following sustainable development principles. Consequently, Hotels are likely to be limited in their ability to use some sustainable attributes as a source of cost based competitive advantage (Stephen Henderson, 2011). Therefore, this research has intended to answer the following questions;

1. Do sustainability practices reduce financial leakages of star classified hotels in Ethiopia?

2. Do the reductions of financial leakage enhance competitive advantage of star classified of hotels in Ethiopia?

\section{Conceptual Model}

This research has developed a conceptual framework consisting of three major constructs. It focuses on sustainability practices (environmental, socio-cultural and economic) causes the reduction of financial leakage and this reduction financial leakage could enhance competitive advantage of tourism business particularly, hotels. The framework of this study is developed based on Resource Based View of Barnly (1991) and TBL Elington, 1986 theories. According to RBV, a firm (e.g. hotel) resource under its controls of valuable, rare, imperfectly imitates and non-substitutable resources help to design and implement strategies that will reduce financial leakage and finally enhance competitive advantages of hotels (Barnly 1991; Leonidou, et al. 2013).

The researcher has proposed a model to explore the relationships among the three pillars of sustainability performance in the tourism business, particularly in hotel businesses (see Figure 1.2). This research model assumes that performance of hotels' environmental, social-cultural and economic sustainability companies is more likely correlated and affect hotels' financial leakage directly and finally enhance competitive advantage of firms. Beside this, scholars and researchers have realized that the appropriate way to maintain continuous economic benefit is when achieving social equity and ecological integrity, which is referred to as the Triple Bottom Line (TBL) (Smerecnik \& Andersen, 2011). 
Figure 1. Conceptual Framework

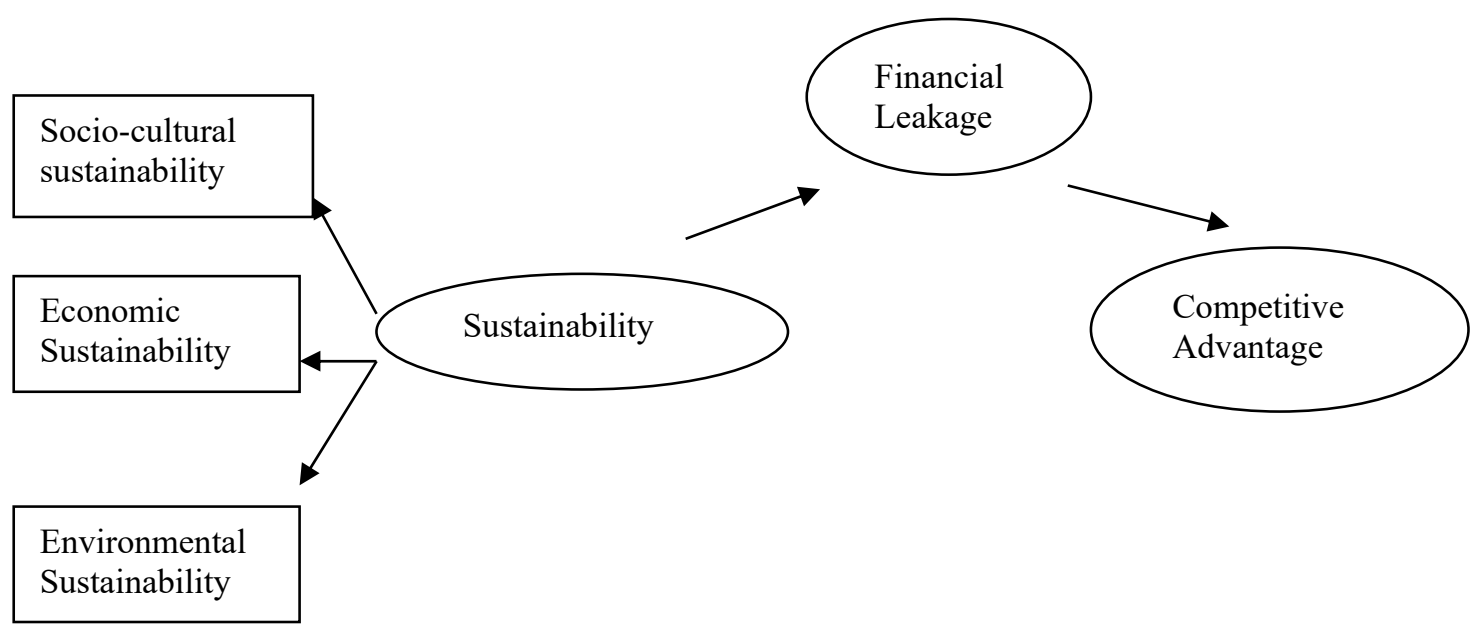

Source: (Research Data, 2020)

\subsection{Development of Research Hypotheses}

The conceptual model used in this research comprises three major hypothesized associations and nine key constructs hypotheses, that link sustainability with financial leakage and financial leakage with competitive advantage. This research model is based on Triple Bottom Line of Elington, 1986 and the resource-based view (RBV) of Barney, (1991). This model underline the firm's resources which are valuable, rare, imperfectly imitable, and non-substitutable resources helps to design and implement strategies that will exploit its own strengths and avoid its internal weaknesses, while responding to environmental opportunities and neutralizing external threats and eventually create sustainable competitive advantages (Barney, 1991). Furthermore, the aggregate score of the TBL reflects the level of sustainability of tourism business (Elkington, 2004), while this TBL sores of the three dimensions of sustainability practices directly affects financial leakage and enhance competitive advantage through reducing financial leakage.

Adopting sustainability practices such as an environmentally friendly strategy and practice and socio-cultural responsibility in hotels can lead to the creation of competitive advantage (Stabler \& Goodal, 1997). A sustainable strategy can significantly reduce costs and improve differentiation offerings from the competing organizations through lowering hotels financial leakage. The use of cheaper recyclable supplies/materials, energy-saving processes, waste-minimization solutions, and operating process improvements significantly lower costs and create differentiation offerings (Porter and Van der Linde, 1995). Sustainability practices can play a vital role to deploy organizations resources in a way to reduce costs associated with water, energy and waste and to formulate ecomarketing strategies that will lower financial leakage (Norman and MacDonald, 2004). Therefore,

H1: Sustainability practices reduce or negatively related to financial leakage of hotels in Ethiopia.

H2: Higher factors Sustainability practices reduce or negatively related to lower factors of financial leakage of hotels in Ethiopia.

$\mathrm{H} 2$ : The reductions of financial leakages enhance or negatively related to competitive advantages of star classified hotels in Ethiopia.

\section{Research Methodology}

\subsection{Study Area}

This study has been conducted in Ethiopia, one of the leading tourist destination found in the heart of the East Africa. The region has attracted millions of tourists each year and the competition of tourism business in the region has showed increment. Ethiopia has enormous natural and cultural resources and become one of the best tourist destinations in East Africa. However, advances in technology and most critically, continually changing customer or employees needs has altered the ways to compete. Hence, in order to hold Ethiopia's competitive position in East Africa, the Ethiopian Federal Democratic Republic of Ethiopia, Culture \& Tourism Minister (MoCT) has begun to standardized tourism businesses such as, hotels, resorts and lodges. Consequently, the target population of this research were all-star classified hotels ranging from one star to five star in the country. For these reasons, A Quantitative and cross-sectional design were employed to collect data at one point in time as time constraints prohibited a longitudinal study (Dillman et al., 2009). 


\subsection{Instrument Development}

Measures used for this research were based on previous studies, with appropriate modifications to suit the characteristics of the tourism industry in Ethiopia. Managers were assumed to give reliable reports about the retrospective data of sustainability practices implementations. The 16 items of the questionnaire for measuring 'financial leakage' and 21 items of questionnaire for measuring 'Sustainability' were adopted from (Alzboun Nidal, et al., 2016). Related literature review and interview has been also conducted. A five point Likert scale $(1=$ Strongly Disagree to $5=$ strongly agree) have been used with minor wording changes to all variables. The questionnaire was administered between September 2018 and June 2019. The process resulted in completed questionnaires from 201 hotels ( $94 \%$ response rate). Therefore, it is sufficient to provide a $95 \%$ confidence level as suggested by (Mendenhall et al., 1993). Regarding validity and reliability, prior to data collection content validity conducted and improvements for measurement model were suggested. This includes changing 6 point lickert scale into 5 points. Then pilot study conducted using twenty five randomly selected hotel managers, the instrument has achieved the required level of reliability (Alpha $>0.7$ ).

\subsection{Data Screening}

Initially, outliers and normality issues were addressed. Specifically, Cook's distance was used to identify outliers. Cook's distance value greater than 1 must be removed to have a better model fit (Chatterjee, S.,2000). Considering this, there was no value greater than 1 that has to be removed. In addition to this, skewness and kurtosis index measures were used to check normality of the data. To result showed all the values of kurtosis and skewness for all the constructs are below 10 and 3 respectively. Hence, the distribution of the data can be considered normal (Kline (2011). Confirmatory Factor Analysis (CFA) was also used to check the validity and reliability of the constructs. The model fit and hypothesis tests were measured by SPSS V.23 \& AMOS V.21 respectively. Therefore, the SEM (Structure equation modeling) was used to test proposed theoretical framework as it is suggested by (Anderson \& Gerbing 1998).

Univariate normality of the data was checked by identifying z-score of skewness and kurtosis using SPSS 23. Items highly skewed i.e. $>3.29$; could be deleted. The result of frequencies found that some of the items were highly skewed, which believed to inflate the estimates greatly (Tabachnick \& Fidell, 2006). Then, the researcher has decided to delete items which are seems categorical in nature and before doing further analyses. These items are the environmental practice of the hotels such as implementing 'no smoking' policy in public areas, reuse packages and/or plastic materials, capture rainwater runoff and reuse it, use treated waste water for garden irrigation and implementing renewable energy programs (wind, thermal), its skewness is due to the cost associated with the practice. The other six skewed items were involved in on imports of food and beverages directly (Fruits and vegetables produced and imported outside the country, meats produced and imported outside the country) and wages to foreign labours in high positions and marketing activities expenses incurred through foreign based media. All these skewed items needed to be removed from the analysis after doing factor analysis (Tabachnick \& Fidell, 2006).

\subsection{Limitations of the Study:}

The most important limitation of this study is the generalizability problem. This study has only involved star classified hotels, under tourism businesses. Hence, it is recommended to validate to other types of tourism businesses in a country. Moreover, the variables used in this research did not incorporate the antecedents of sustainability practices and the impact of competitive advantage on hotel businesses performances. Therefore, in directions for further study capabilities, implementation of an eco-friendly marketing strategy as antecedents of sustainability practice and financial and nonfinancial performance as outcome of competitive advantage could be included.

\section{Analysis and Findings}

The data collected in this study were descriptive statistics used to determining the level of financial leakage of these star classified hotels in the country. Furthermore, inferential statics were used to check the validity and reliability of the measurement model include composite reliability and average variance validity statistics of both the exogenous and endogenous constructs and to test the study hypotheses.

\subsection{Descriptive Statistics Result}

\subsubsection{The Degree of Financial Leakage of Star Classified Hotel in Ethiopia}

As one of the main objective of this study, the level of financial leakage of tourism business specifically, star classified hotels in Ethiopia were surveyed. A financial leakage has been described in the form of food and beverage, material and equipments and remittance. Hotel managers were asked to answer questions listed under the three sub-dimensions of financial leakage $(16$ items, Alpha =.677). Specifically; food and beverage $(5$ items, Alpha $=.677)$, materials and equipments $(6$ items, Alpha $=.613)$, and remittance $(6$ items, Alpha $=.785)$. Therefore, 
the overall internal consistency of these 16 items of financial leakage was (Alpha $=.793$ ).

Table no 1. Items used to measure financial leakage (Alpha, .896)

\begin{tabular}{|c|c|c|c|}
\hline No. & Items & Mean & S.D \\
\hline & Financial Leakage & 3.05 & .071 \\
\hline Foo & d \& Beverage & 2.9 & .066 \\
\hline & Fruits \& vegetables produced and imported outside the Country & 2.01 & .061 \\
\hline & Meats produced and imported outside the country & 1.93 & 062 \\
\hline 3 & Sausage and other ingredients produced and imported outside the country & 3.30 & .066 \\
\hline 4 & Alcoholic beverages prepared and imported outside the Country & 3.0 & 064 \\
\hline & Tea \& coffee, prepared and imported outside the country & 2.96 & .079 \\
\hline & Non-alcoholic beverages prepared and imported outside the country & 3.38 & .065 \\
\hline Mat & erial \& Equipment & 335 & .074 \\
\hline & Kitchen wares, manufactured and imported outside the country & 3.36 & .070 \\
\hline & Furniture (used as substitutive to old ones), outside the country & 3.34 & .072 \\
\hline & Electronic equipment, manufactured and imported outside the country & 3.52 & .077 \\
\hline & Stationery, manufactured and imported outside the country & 3.29 & .074 \\
\hline & Decor and/or other construction materials, imported outside the country & 3.28 & .075 \\
\hline Rem & nittance & & .073 \\
\hline 12 & Management expenses, if the hotel is managed by foreign based organization & 3.28 & .069 \\
\hline & $\begin{array}{l}\text { Reservation system expenses, if it has been installed and/or being managed by } \\
\text { foreign based organization }\end{array}$ & 2.26 & .067 \\
\hline 14 & Wages to foreign labours in high positions & 3.12 & .078 \\
\hline 15 & Commissions paid for foreign tour operators and agencies & 3.25 & .068 \\
\hline 16 & Marketing activities expenses incurred through foreign based media & 2.69 & .082 \\
\hline
\end{tabular}

Source: (Researchers, 2020)

As the table above table no.4.1 showed, the overall level of financial leakages were higher than the average value that is $(\mathrm{m}=3.05)$. Specifically, kitchen wares, manufactured and imported outside the country with average value of $(\mathrm{m}=3.36)$ and electronic equipments, manufactured and imported outside the country with the average value of $(\mathrm{m}=3.52)$ were items frequently hotels faced to import abroad. The result of interview made with hotel managers revealed that the standard level of raw materials produced in the country is below the international standards that the hotel has to fit complied with. Secondly, financial leakage 'Remittances' were the most important category of financial leakage that hotels in Ethiopia have become challenged. In particular, management expenses paid to foreign based organization $(\mathrm{m}=3.28)$ and commissions paid for foreign tour operators $(\mathrm{m}=3.25)$ for which they had paid huge commissions were the source of financial leakage of these star classified hotels in the country.

Thirdly, the food and beverage financial leakage were slightly lower than the aforementioned sources of financial leakages. Only hotels have mostly been using alcoholic beverages prepared and imported outside the country $(\mathrm{m}=3.30)$ and sausage and other ingredients produced and imported outside the country $(\mathrm{m}=3.30)$. It is because; these kind of items were not available with the required quality and quantity level, while most of the food items were currently available locally that could meet the international standards. Overall, hotels were lag behind the expected degree of financial leakage and have to go further to reduce the possibility of financial leakage occurred in a way that would enhance their performances.

\subsection{Validity and Reliability Tests for the Study Measurement Model}

Due to the nature of the data, maximum likelihood method of estimation was used. Items and factors of the study were adopted from (Alzboun, et al., 2016). For the reason, all of the items which had factor loadings greater than 0.40 , were summed to form a measure. As the table no 4.11 Cronbach's alpha, was used to assess the internal consistency and reliability of the resulting factors using the composite reliability (CR) and the average variance extracted (AVE). For the composite reliability, the values exceeded the minimum value of $>0.7$ for (Nunnally and Berstein, 1994) and for AVE all constructs were exceed 0.5 (Barclay, et al., 1995). To determine the discriminate validity, the results of correlation analysis and the square root of AVE were considered. To this end, the square root of each dimensions' AVE were higher than the correlation between the dimensions as the table no. 4.2 below shown. Furthermore, model fit tests have been checked and all have transcend the thresholds recommended by (Kline, 2011). These includes $\mathrm{CMIN} / \mathrm{DF}=1.011, \mathrm{P}=, .431, \mathrm{CFI}=0.99 ; \mathrm{GFI}=0.90 ; \mathrm{AGFI}=$ $0.89 ; \mathrm{SRMR}=0.46$; and $\mathrm{RMSEA}=.008$. 
Table no. 2. Validity and Reliability for Second Order Measurement

\begin{tabular}{|l|l|l|l|l|l|l|l|}
\hline & CR & AVE & MSV & MaxR(H) & COMP & QTE & SUSP \\
\hline COMP & 0.725 & 0.571 & 0.319 & 0.757 & $\mathbf{0 . 7 5 6}$ & & \\
\hline QTE & 0.834 & 0.558 & 0.319 & 0.843 & 0.565 & $\mathbf{. 7 4 7}$ & \\
\hline SUSP & 0.777 & 0.55 & 0.114 & 0.906 & .338 & .286 & $\mathbf{0 . 7 4 2}$ \\
\hline
\end{tabular}

Source: (Researchers, 2020)

\subsection{Hypothesis Testing}

\section{The Effect of Sustainability on Financial Leakage}

As part of the main investigation, $\mathrm{H} 1$ deals with the relationship between sustainability and financial leakage. The result indicated that the greater sustainability of hotels, the higher hotels' financial leakage $(\beta=0.328, \mathrm{P}=.009)$. Albeit, the relationship was expected tobe negative i.e. the higher sustainability resulted in the lower financial leakage of star classified hotel business in Ethiopia. Hence, this research finding does not support the hypothesis of this research i.e. the higher sustainability practices by star classified hotels in Ethiopia could not resulted in lower financial leakage.

\subsection{The Effects of Lower Order Factors of Sustainability on Lower Factors of Financial Leakage}

$\mathrm{H} 2$ pertains to the effect of sustainability practices on the reduction of financial leakage in terms of importing food and beverage, materials and equipment and remittance. The results shows that environmental factor has $(\beta=.154$, $\mathrm{P}=.200, \beta=-167, \mathrm{P}=.166, \beta=0 .-.154, \mathrm{P}=.200)$ effect on the lower factors of lower financial leakage i.e. food and beverage, materials and equipment and remittance respectively. The second lower factor of socio-cultural also has $(\beta=-.185, \mathrm{P}=.548, \beta=.105, \mathrm{P}=.493, \beta=-.185, \mathrm{P}=.235)$ effect on the lower factors of lower financial leakage i.e. food and beverage, materials and equipment and remittance respectively. Furthermore, the second lower factor of economic sustainability also has $(\beta=.477, \mathrm{P}=.009, \beta=.309, \mathrm{P}=.090, \beta=.435, \mathrm{P}=.018)$ effect on the lower factors of lower financial leakage i.e. food and beverage, materials and equipment and remittance respectively. This is consistent with the findings of a study by (Alzboun Nidal, 2016), which supports this research findings. It is obvious that using energy efficient equipment prevents extra costs incurred for maintenance and exchange equipment frequently. The hotel guest consumes energy threefold a person uses at home. Hence, it became the primary challenge for the hotel industry and the country as a well. Therefore, businesses became aware of the contribution to decreasing the operational costs and consequently increasing their profitability.

\subsection{The Effect of Financial Leakage on Competitive Advantage}

Hypotheses 3 posit the relationship between financial leakage and competitive advantage is negative. The result indicate a slightly lower financial leakage in the hotels, could achieve slightly higher competitive advantage ( $\beta$ $=.219, \mathrm{P}=.019)$. The result is in harmony with the study done by (Chi \& Gursoy, 2009; Galdon, et al., 2013). These researchers have found reducing leakage has created a higher level of satisfaction among customers and employees, thereby improving a firm's competitive position. Hotels could achieve a competitive advantage if they could reduce the financial leakage to the level required. To this end, the higher financial leakage associated with the hotel operations could encourage the hotels to reduce its price and be competitive. A cost cutting is important for a firm to operate at a lower cost than its competitors but provide a comparable service so as to achieve a cost advantage (Porter, 1985).

\section{Conclusion and Recommendation}

The result indicated that the effect of sustainability on financial leakage of hotels i.e. the effect of sustainability on the financial leakage could be the long term vision of a firm, which could not be achieved in the short term (Denning 2005; Grissemann et al. 2013). Beside this, the qualitative analysis of this research has identified the reason behind this finding. Due to the challenges associated the expensiveness of some of the technologies required to implement sustainability practices to the level expected could not enabled hotels to implement them and achieved a higher sustainability performances, which consequently did not resulted in lower a financial leakage among star classified hotels in Ethiopia. Moreover, the interviews made with the hotel managers assert some of the financial leakages are expected reasonably to be occurred. This includes expenses related with technological appliances and equipments. Lastly, hotel managers assert that the link between raw materials producers and the principals such as hotels, resorts and lodges were weak in the case of Ethiopia. This comment has supported by authors in the area. According to Lacher \& Nepal (2010) in the country where there is weak economy and lacks integrations, the financial leakage would be higher.

It was expected that the higher economic, socio-cultural and environmental factor the lower food and beverage, material and equipment and remittance factors. However, other than economic factor, the lower factor factors of sustainability i.e. socio-cultural and environmental factor does not significantly reduced the level of 
financial leakage of star classified hotels in Ethiopia. Hence, hotels have achieved viable economic sustainability in the lower food \& beverage, material \& equipment and remittance financial leakages of star classified hotels in Ethiopia. It is because hotels were applying cost effective and sustainable activities such as hiring local persons and start to attract local customers, other than foreign tourists. Therefore, star classified hotels in Ethiopia and its sustainability practices were not to the level expected so as to reduce their financial leakages.

Nonetheless, it is significant that in all of them the main factor influencing the level of sustainable development is financial. This is realized mainly by cost reductions, which are achieved by improving efficiency and reducing consumption of resources. There are many associated benefits from improved 'environmentally friendly' energy consumption in hotels and other tourist venues, such as improving customer loyalty, enhancing public image, attracting and retaining dedicated staff, avoiding penalties from environmental authorities, and other long-term operational advantages (ESCWA, 2003).

According to the interview made with the hotel managers, the reason behind that the studied hotels could not lower their financial leakages is that mainly due to the economic nature of the country. It is believed that tourism industry in less developed nations having instability problems could not take full advantage of substituting imported goods with locally produced goods. This lack of producing imported materials within tourist destinations has been hindering factor for the economy and consequently brought a high level of financial leakages for the tourism businesses. More importantly, some hotels and resorts in these nations were not in a position to use locally available goods due to the brand given for local goods are less than imported (Hall, M., \& Sharples, L., 2003).

The objective of this study was to assess the sustainability practices and its effect on reduction of financial leakage of star classified hotels in Ethiopia under the RBV theoretical background. The study has applied crosssectional approach. This research has also studied the reduction of financial leakage and its effect on competitive advantage of the studied hotels. This study has used SEM using Amos 21 version. This study has brought the following answers for the research questions identified based on reviewed literatures. It was found that sustainability practices had a positive effect on financial leakage of star classified hotels in Ethiopia. It reflects the sustainability practices of star classified hotels could not reduce financial leakage of the studied hotels in Ethiopia. However, the growing trend in the tourism business showed that market of environmentally firms that care about the environment could reduce financial leakage greatly (Han, Hsu, \& Sheu, 2009; Rodriguez \& Cruz, 2007). This study finding is different from existing literatures (e.g., Carmona-Moreno et al., 2004; Claver-Cortés et al., 2007). It might be because of the existing situation in Ethiopia and the way sustainability practices implemented need to be re-evaluated that support the future sustainability impacts on financial leakage and competitiveness of the tourism industry.

Recommendation: consequently, hotels should take actions that aimed at cutting costs that lower the selling prices than its competitors, which finally result in a larger market share (Aznar, 2016). Specifically, hotels need to work with local producer that will support the income earned from tourism activities spend locally, create jobs for local community and finally enhance their image (Lacher \& Nepal, 2010). Furthermore, sustainability practices considering the Triple Bottom Line (TBL) could mitigate financial leakage problems in hotels (Supradist, 2004) and could enhance competitive advantage of the hotels. To address this issue, a research done by Galdon, et al. (2013) found that reducing leakage has the potential to improve the level of satisfaction among employees and customers, thereby improving a firm's competitive advantage. Eventually, researchers have realized that multiplier effect could be affected by the level of sustainable tourism development practices within tourism business of a tourist destination (Karagiannis, 2004).

\section{Reference}

Alberto J. Aragon-Correa \& Enrique A. Rubio-Lopez, (2007). Proactive Corporate Reporting Environmental Strategies: Myths and Misunderstandings. Long Range Planning 40(3), 357-38.

Yenidogan, A., Gurcaylilar-Yenidogan, T., \& Tetik, N. (2016). Sustainability Reporting in the Hospitality Industry: A Research Model Proposal on Sustainability Performance. In International Conference on Economic Sciences and Business Administration ,3,(1), 79-86).

Alzboun, N., Khawaldah, H., Backman, K., \& Moore, D. (2016). the effect of Sustainability practices on financial leakage in the hotel industry in Jordan. Journal of Hospitality and Tourism Management, 27, 26-28.

Anderson, J. C., \& Gerbing, D. W. (1988). Structural equation modelling in practice. A Management Journal, 14, (1), 33-46.

Aragon Correa J.Alberto (1998). Strategic Proactivity and Firm Approach to the Natural Environment'. Academy of Management Journal, 41 (5): 556-567.

Baker William E. and Sinkula M. James (2005). Environmental Marketing Strategy and Firm Performance: Effects on New Product Performance and Market Share. Journal of Academy of Marketing Science, 33(4),

Barclay D, Higgins C, Thompson R (1995). The Partial Least Squares (PLS): Approach to causal modeling: personal computer adoption and use as an illustration. Technology studies 2: 285-309. 
Barney Jay (1991). Firm Resources and Sustained Competitive Advantage; journal of Management, 17(1)

Butler, R. W. (1991). Tourism environmental and sustainable development. Environmental conservation. Pearson. $1^{\text {st }}$ ed. Wiley.

Chi, G.C. and Gursoy, D. (2009), Employee Satisfaction, Customer Satisfaction and Financial Performance: An Empirical Examination. International Journal of Hospitality Management, 28, 245-253.

Chatterjee, S., Hadi, A.S., Price, B. (2000). Regression Analysis by Example, $3^{\text {rd }}$ edition, Wiley, New York.

Claver-Cortés, E., Molina-Azorín, J.F., Pereira-Moliner, J. and López-Gamero, M.D. (2007)."Environmental strategies and their impact on hotel performance. Journal of Sustainable Tourism, 15 (6), 63-679.

Dillman, Don A., Jolene D. Smyth and Leah Melani Christian. (2009). Internet, Mail, and Mixed-Mode Surveys: The Tailored Design Method, 3rd Edition. New York: John Wiley and Sons, Inc.

Dwyer, L. (2005). Relevance of triple bottom line reporting to achievement of sustainable Tourism. A scoping study. Tourism Review International; 9(1), 79-94.

Dyllick Thomas and Hockerts, Kai (2002). Beyond the Business case for Corporate sustainability. Business Strategy and the Environment, 11, 130-14.

Elkington, J. (1998).Cannibals with forks: 1he triple bottom line o/21" century business. Gabriela Island, BC: New Society Publishers.

Galdon, Jose,AU - Garrigos-Simon, Fernando, Gil-Pechuán, IgnacioPY (2013). Leakage, Entrepreneurship, and satisfaction in hospitality. Service industries Journal. 33, 7-8.

George Assaf, Alexander Josiassen, Ljubica Knezevic Cvelbar (2012). Does Triple Bottom Line reporting improves hotel performance?. International Journal of Hospitality Management. 31(2), 596-600.28 (2)-3, 73-89.

Han, H., Hsu, L.-T., \& Lee, J.-S. (2009). Empirical investigation of the roles of attitudes toward green behaviors, overall image, gender, and age in hotel customers' eco-friendly decision-making process. International Journal of Hospitality Management, 28(4), 519-528.

Hughes, G. (1995). The cultural construction of sustainable tourism. Journal of Tourism Management, 16(1), 4959.

Sousa Filho, J. M. D., Wanderley, L. S. O., Gómez, C. P., \& Farache, F. (2010). Strategic corporate social responsibility management for competitive advantage. BAR-Brazilian Administration Review, 7(3), 294-309.

Juan Pedro Aznar \& Josep Maria Sayeras \& Jorge Galiana \& Alba Rocafort, (2016). Sustainability Commitments, New Competitors Presence and Hotel Performance: The Hotel Industry in Barcelona Sustainability. MDPI, $8(8), 1-13$

Karagiannis,,N (2004).The Caribbean Economies in an Era of Free Trade. $1^{\text {st }}$ ed. Ashgate: Aldercroftl.

Kasim A. (2009). Managerial attitudes towards environmental management among small and medium hotels in Kuala Lumpur. Journal of Sustainable Tourism, 17 (6), 709-725.

Kline, R.B. (2011) Principles and Practice of Structural Equation Modeling. Guilford Press, New York.

Konstantinos A., (2002). Scale of hospitality firms and local economic development Evidence from Crete. Tourism Management, 23(4), 333-341.

Kline, R.B. (2011) Principles and Practice of Structural Equation Modeling. Guilford Press, New York.

Krikelas, A. C. (1992). Why regions grow: A review of research on the economic base model. Economic Review, 16-29.

Lacher, R. G., \& Nepal, S. K. (2010). From leakages to linkages: Local-level strategies for capturing tourism revenue in Northern Thailand. Tourism Geographies,12(1), 77-99.

Lejárraga, I. and Walkenhorst, P., (2010). On Linkages and Leakages: Measuring the Secondary Effects of Tourism. Applied Economic Letters, 17(5), 417-421.

Leonidou, LC, Fotiadis, TA, Leonidou, CN et al. (2013). Resources and capabilities as Drivers of hotel environmental marketing strategy: Implications for competitive advantage and performance. Tourism Management, 35 (2). 94-110.

Mendenhall, M., Beaty, D. and Oddou, G. (1993). "Where have all the theorists gone? An archival review of the international management literature. International Journal of Management, 10( 2), 146-53.

Meyer, D. (2007). Pro-Poor Tourism: From Leakages to Linkages: A Conceptual Framework for Creating Linkages between the Accommodation Sector and Poor "Neighboring Communities. Current Issues in Tourism, 10(6), 558-583.

Mihalič, T. (2000). Environmental management of a tourist destination: A factor of tourism competitiveness. Tourism Management, 21(1), 65-78. 148.

Mihalic, T., Zabkar, V., \& Cvelbar, L.K. (2012). A hotel sustainability business model: evidence from Slovenia. Journal of Sustainable Tourism, 20(5), 701-719.

Nunnally, J.C. and Bernstein, I.R. (1994) Psychometric Theory. McGraw-Hill, New York. Rahman, I., Reynolds, D., \& Svaren, S., 2012).

Diamantis D. (2010). The Concept of Ecotourism: Evaluation and Trends; Current Issues in Tourism Eco- 
Management and Auditing. Journal.Taylor \& Francis, 2(2), 93-122.

Mowforth, M.; Munt, I. (1998). Tourism and Sustainability: $1^{\text {st }}$ ed. A New Tourism in the Third World; Routledge: London, UK.

Norman, W., \& MacDonald, C. (2004). Getting to the bottom of the TBL. Firm Ethics Quarterly, 14 (2), 1-19.

Porter, M. E. (1985). "Competitive Advantage", $1^{\text {st }}$ ed. New York: Free Press.

Porter, M.E. and van der Linde, C. (1995) Toward a New Conception of the Environment- Competitiveness Relationship. The Journal of Economic Perspectives, 9 (4), 97-118.

Rahman, I., Reynolds, D., \& Svaren, S. (2012). How "green" are North American hotels? An exploration of lowcost adoption practices. International Journal of Hospitality Management, 31 (3), 720-727.

Rodenburg E.E (1989).The effects of scale in economic development: tourism in Bali. Annals of Tourism Research, $7(2), 177-196$.

Rodriguez, F. J. G., \& Cruz, Y. D. M. A. (2007). Relation between social-environmental responsibility and performance in hotel firms. Hospitality Management, 26 (4), 824-839.

Sharma, S., \& Vredenburg, H. (1998). Proactive corporate environmental strategy and the development of competitively valuable organizational capabilities. Strategic Management Journal, 19 (8), 729-753.

Smerecnik, K.R. \& Andersen, P.A. (2011). The diffusion of environmental sustainability innovations in North American hotels and ski resorts, Journal of Sustainable Tourism, 19(2), 171-196.

Spenceyley, A. (2001). Integrated Biodiversity into the tourism sector: Best Practice and Country Case Studies. UNEP Biodiversity Planning Support Programme (BPSP). Institute of Natural Resources, South Africa. Technical Report. Available at https:/www.researchgate.net/publication/280319301 (accessed October 2017)

Stabler, M.a.J., Goodal, B., (1997). Environmental awareness action and performance in the Guernsey hospitality sector. Tourism Management, (18), 19-33.

Stephen Henderson (2011). "The development of competitive advantage through Sustainable event management", Worldwide Hospitality and Tourism Themes, 3 (3), 245-257.

Supradist, N. (2004). Economic leakage in tourism sector. Master Thesis, Unpublished.Lund, Lund University. UNEP and WTO (2005). Making Tourism More sustainable. A Guide for Policy Makers. Madrid, Spain. WCED (1987). From One Earth to One World: An Overview. Oxford: Oxford University Press. 